\title{
Field biology, food web models, and management: challenges of context and scale
}

\author{
Mary E. Power
}

Power, M. E. 2001. Field biology, food web models, and management: challenges of context and scale. - Oikos 94: 118-129.

\begin{abstract}
Managers are increasingly aware of the need for science to inform the stewardship of natural lands and resources. If ecologists are to address this need, we must increase the scope of our inferences, while maintaining sufficient resolution and realism to predict trajectories of specific populations or ecosystem variables. Food chain and simple food web models, used either as core or component hypotheses, can help us to meet this challenge. The simple mass balance logic of dynamic food chain or food web models can organize our thinking about a range of applied problems, such as evaluating controls over populations of concern, or of biotic assemblages that affect important ecosystem properties. In other applications, a food chain or web may be incorporated as one element in models of regional mass balances affecting resources or environments. Specific predictions of food web models will often fail because of inadequate resolution (e.g., of functionally significant differences among taxa within "trophic levels") or insufficient scope (e.g., of spatio-temporal variation over scales relevant to management). Increasing use of tracers to delimit spatial scales of food web interactions will reduce, but not eliminate, this limitation. If used with skepticism and vigilance to local natural history, however, food chain or simple food web models can promote the iterative feedback between prediction, falsification by observation, and new prediction central to hypothetico-deductive science and adaptive management. Experience argues that this stepwise path is the fastest towards better understanding and control of our impacts on nature.
\end{abstract}

M. E. Power, Dept of Integrative Biology, Univ. of California, Berkeley, CA 94720, USA (mepower@socrates.berkeley.edu).

\section{Overview}

In this paper, I will argue that dynamic food chain or simple food web models, because of their compelling mass balance logic, are useful in framing management problems. These models can also serve as initial null hypotheses, guiding the investigation of key natural history and environmental variation that drive real management problems. Predictions of these models will often fail, but they will leave us with more focused and coherent sets of assumptions and alternate hypotheses to investigate, hastening our approach to more predictive understanding. First, I will describe how hypothetically driven adaptive management might apply simple food web models in a real setting, Santa Cruz Island of coastal California. Then I will use a food chain framework to address the widely sought but somewhat slippery goal of defining "ecosystem health", in the context of a watershed. I next discuss lake management, where food chain theory has been most extensively applied and has engendered some controversy. The variable success of food web biomanipulations in lakes has been explained and predicted by a new model, scaled up to the lake watershed and targeted to predict the amount of phosphorus in the lake water column (Carpenter et al. 1999). This approach incorporates trophic interactions as a component, rather than a core, of a lake management models. Appreciating the spatial scales of key biogeochemical fluxes through food webs will help us determine how much we must expand our scope to

Accepted 14 February 2001

Copyright (C) OIKOS 2001

ISSN 0030-1299

Printed in Ireland - all rights reserved 
encompass stresses and drivers affecting management targets, be these species, populations or ecosystem properties. We have help here from the increasing availability and use of food web tracers, such as stable isotopes. I close with two descriptions of ongoing environmental crises: land use effects on salmon-bearing rivers in western North America, and mining impacts on the Fly River of Papua New Guinea. These situations, like most environmental problems, are complex and large in scale. Crucial decisions will be made before we attain predictive understanding of the systems. In both cases, isotope tracers suggest habitats, energy sources and species interactions that may be keys to the system's future. Food chain or food web models, merged with dynamics scaled to real landscapes, will seldom be initially predictive, but will make our subsequent monitoring and experiments much more informative.

\section{The need}

Human impacts on ecosystems grow more conspicuous, and more global, over time intervals now short enough to capture public attention. As we watch the world change at this accelerating pace, many feel growing concern for nature, and for nature's services (Arrow et al. 1995, Levin 1996, Daily 1997). North Americans are finally beginning to accept what Europeans have been saying for decades: Natural ecosystems must be managed, even to preserve aspects of their wildness (Vitousek et al. 1997). Large national and provincial parks of the US and Canada are not large enough to sustain natural processes needed for maintaining native ecosystems (e.g., historic fire regimes, survival of species with global migrations), or to shield these ecosystems from anthropogenic threats (e.g., exotic invasive species, air pollution).

This realization has transformed the mission and strategy of successful conservation organizations like The Nature Conservancy. Over the last decade, The Nature Conservancy has shifted from somewhat opportunistic land acquisition to "Conservation by Design". This strategy asks "What geographic regions and what management of these regions will sustain species, habitats, or natural processes into the foreseeable future?" It requires a large increase in the spatial scale of planning. In the midwestern US, The Nature Conservancy is a partner with government agencies and local conservation groups in a multi-state effort to conserve entire migratory corridors for waterfowl flying from wintering grounds in the Neotropics to North American breeding grounds. In California, the strategy has been to save ten representative "ecoregions", and within these, entire large watersheds. One exciting example is the program to protect, and partially restore, the floodplain and upper watershed of the Cosumnes River, the last free-flowing river in California to drain from the Sierra Nevada into the Pacific. Here, The Nature Conservancy has used an elevationally stratified strategy. The organization acquired flood-prone bottom lands from willing sellers, and is experimentally breaching levees to restore floodplain function and riparian forest. Upslope, they have purchased conservation easements that allow owners to manage their lands in ways more hospitable to native species (e.g. cattle grazing rather than conversion to vineyards). The Nature Conservancy has also partnered with nature-friendly enterprises within the upper Cosumnes watershed, such as organic dairy and organic rice farming.

While they have unique expertise to design and protect "portfolios" of natural lands, Nature Conservancy leaders acknowledge that in some cases, they lack sufficient expertise to manage these lands so as to maintain the ecosystems they had hoped to preserve. For example, Santa Cruz Island, a "crown jewel" in their California portfolio, had residual populations of cattle, sheep, and pigs, legacies of the island's ranching history. These grazers damaged vegetation, including endangered unique, endemic plants. With great effort and some cost to public relations, The Nature Conservancy eradicated cattle and sheep from the rugged $46 \mathrm{~km}$ long island (Martin 1998). In response, however, European fennel (Foeniculum vulgare), previously suppressed by grazing, burgeoned to become the island's dominant plant. Fennel now provides high quality forage and cover for feral pigs, and has supported a huge increase in their population. The pigs devastate large areas of steep hillslopes by their erosive grubbing. The even more damaging responses by fennel and pigs to cattle and sheep eradication were not anticipated. Undesirable changes on this and other properties have led The Nature Conservancy to turn to ecologists for information and insight, to support the crucial goals of anticipating ecosystem change, and managing it. Are we prepared to supply useful advice?

\section{The challenge}

Not really. Few ecologists feel that we can confidently predict consequences of specific management changes over the large scales needed. Ecology can be reasonably described as the most complex system science has ever tried to understand. Organisms and ecological communities are embedded in heterogeneous, fluctuating environments. Physical and biotic factors exert effects on population dynamics that are typically non-linear, and mediated through webs of complex interactions. The performances of organisms, and their consequent impacts on environments, communities, or ecosystems, will depend on evolved characteristics of the biota, and 
the environmental context, including the timing of environmental changes relative to organisms' life histories and seasonal phenologies. Feedbacks between organisms, environment, and ecosystems occur over a wide range of temporal and spatial scales (Frost et al. 1988), which are proving larger than ecologists had previously anticipated (Polis et al. 1997, Chadwick et al. 1999, Thompson et al. in press). Clearly, we face big challenges in our efforts to anticipate ecological effects of natural or human induced changes and to steer managed ecosystems towards states we prefer.

\section{The approach}

The hypothetico-deductive method is a time honored approach to complex problems. First, we formulate a simple model based on observations, study why its predictions fail, and re-formulate the model based on what has been learned by its failure. Multiple competing hypotheses clearly assist and accelerate this process at every stage (Chamberlin 1890, Turchin 2001). Ecologists (e.g., Holling 1978, Walters 1986, Starfield and Bleloch 1986) who have had broad experience modeling complex management problems have recommended that the interactions in this process - between models, observational tests, and reformulations of new models to be tested with new data - be very short (Fig. 1). Shelves of environmental agencies are full of dusty notebooks of unused data that were collected for too long in the absence of clear hypotheses (lower right corner of Fig. 1). On the other hand, many elaborate (over-parameterized) ecosystem models have been con-

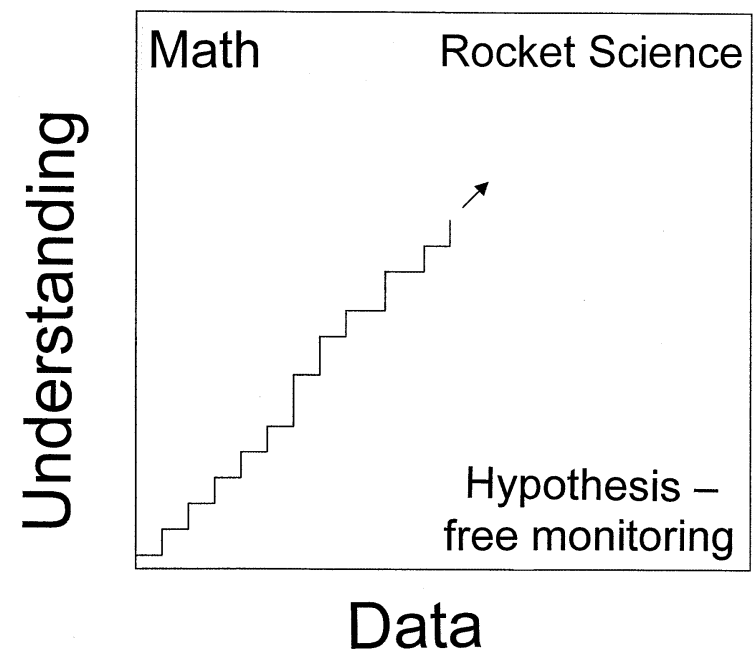

Fig. 1. Relationship between data and understanding, modified from Starfield and Bleloch (1986) and Holling (1978)

"Throw away models" (A. S. Starfield pers. comm.) frequently tested and discarded or reformulated with field observations, may be the most efficient path for ecology to move from near the origin towards "rocket science". structed, but never fully parameterized, let alone validated with new data. The advantages of simple models are well understood. Simple models are testable, discardable (not replete with invested effort, so easier to reject when falsified), and more transparent, to scientists and non-scientists alike. But their predictions may not be specific enough to guide management.

Through stepwise iteration between models and field observation, we hope to relax simplifying assumptions and reformulate models until they capture enough reality to make useful predictions. Applying this approach to ecological management requires that we agree on what scale (i.e., what range over which measurements are averaged Levin and Pacala (1997)) of information we need for particular management goals. Management sometimes targets species: populations that we want to harvest at sustainably (resources), to suppress or eradicate (our own competitors, parasites, and pathogens), or to preserve for biodiversity conservation. Even when management goals focus on one or a few species, however, a food web perspective is necessary because the population dynamics of any species depend critically on how their resources, prey, and potential predators and pathogens also respond to environmental change (Weisberg and Burton 1993, Power et al. 1996a, 1997, Wootton et al. 1996).

Food chain models (Smith 1969, Sykes 1973, Fretwell 1977, Oksanen et al. 1981, Getz 1984, Oksanen 1991) give us a skeletal framework connecting the gain and loss equations of trophically linked populations. In the case of Santa Cruz Island, trophic interactions are clearly important. Fennel and endemic plants are grazed by cattle, sheep, pigs. Two of these grazers were extirpated by hunters (Fig. 2a). A simple three-level food chain model, however, would have failed to predict the fennel explosion on Santa Cruz Island, because functionally crucial differences among both plants and grazers would not be resolved. The conservation focus is on native plants, not total green biomass including fennel. In the "second trophic level", cattle and sheep suppressed fennel, while pigs, it turns out, do not. In addition to having inadequate biological resolution, simple food chain models would not have captured crucial non-trophic processes. These include erosion from pig trampling which facilitates the spread of fennel, and space competition with native plants by fennel. Another indirect effect that in retrospect proved important was an interaction modification (sensu Wootton 1994): fennel provided cover from hunters for pigs. A reformulation of a more complete interaction web (sensu Menge and Farrell 1989) based on the outcome of the first management action (Fig. 2b) suggests that pig eradication would be facilitated if fennel could be suppressed. A reformulated model incorporating this hypothesis could suggest several management options: planting of native trees to shade fennel; finding speciesspecific biological enemies or toxins of fennel, or (a 
a)

Human Hunters

Cattle, Sheep, Pigs

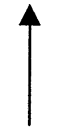

Plants

b)

\section{Human Hunters}

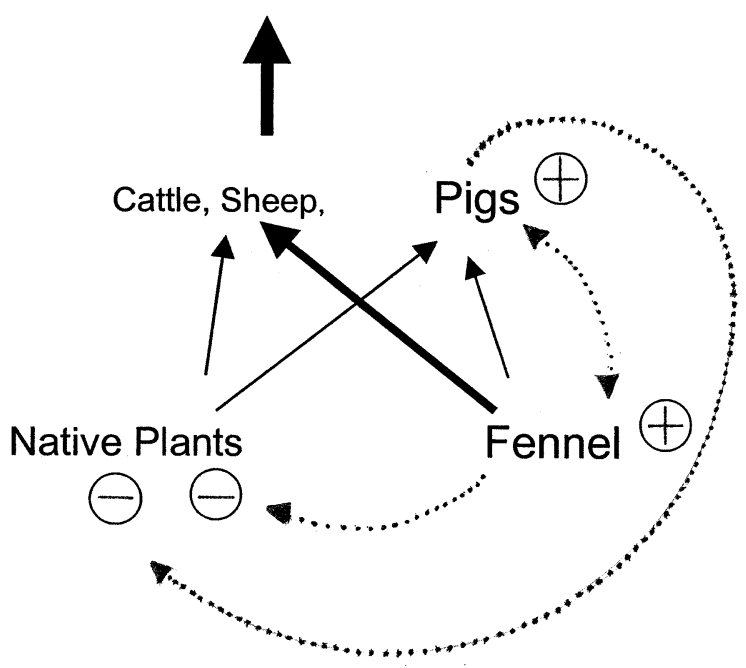

Fig. 2. Food chain (a) and interaction web (b) relevant to management of exotic grazers and fennel, and threatened or endangered endemic plants on Santa Cruz Island, California. The interaction web depicts relative interaction strengths (thickness of arrows) and indirect interactions crucial for management understanding. A mutually positive interaction occurs between pigs and fennel. Erosion by pigs enhances fennel spread into disturbed grubbed soil; fennel makes pigs less visible to hunters. Fennel indirectly harms native plants by space preemption; pigs ingest native plants, but also harm them indirectly by erosive trampling and grubbing.

radical option, not under present consideration) reintroducing cattle to the island, allowing them to graze down fennel until pigs could be hunted to extinction, and then removing the cattle again. In the spirit of adaptive management (Walters 1986), consequences of these actions would be used to reformulate more models hypothesizing how the crucial controls on the food web really work, and these would be tested with new data and observations.

\section{Aquatic vs terrestrial applications}

While trophic cascades occur in both terrestrial and aquatic ecosystems (Schmitz et al. 2000), it is in the latter that food chain models have their longest history of application to management. Some of the earliest mathematical food chain models were motivated by concerns for drinking water quality (Smith 1969, Sykes 1973). Subsequently, these approaches have been scaled up to seek solutions for problems in lake and watershed management. Biomanipulation, a management approach that posits that consumers in lakes can limit algal populations below "nuisance" levels, has engendered widespread interest (Shapiro 1979, Carpenter et al. 1985, 1987, Carpenter and Kitchell 1992, Kitchell 1992, Carpenter and Cottingham 1997). It has also provoked some skepticism. Questions arose about whether trophic connections were sufficiently coherent, particularly between phytoplankton and grazers, to allow top down control over eutrophication (McQueen et al. 1986, DeMelo et al. 1992). While some of these arguments derived from misinterpretations of grazer-phytoplankton correlations, which are unimodal (Carpenter and Kitchell 1984), real mechanisms could release algae from control by zooplankton: demographic escape under favorable growth conditions (algal generation times are more than an order of magnitude shorter than those of zooplankton), or increasing dominance of inedible taxa (Leibold 1989), some even after ingestion (Porter 1973). In the second case, food chain models fail because they inadequately resolved primary producers (into edible and inedible taxa). In the first case, the failure can be considered one of scope, and insensitivity to spatial context: some lakes receive more nutrients than animals in food webs can assimilate and store.

Acknowledging that food chain models are often insufficient for prediction, we can still use them to frame and communicate management issues. Below, in the context of an increasingly widespread problem for water-limited, expanding human population centers, I outline how a simple linear food chain model can depict varying degrees of "ecosystem health". Then I will discuss more concrete applications in temperate lakes, upland salmon-bearing rivers, and a lowland tropical floodplain river, in which simple food chain models have been or could be expanded in scope, resolution, or sensitivity to spatio-temporal context, in order to improve their usefulness as management tools. 


\section{Simple food chain models and evaluation of aquatic ecosystem "health"}

Basic food chain models relate functional (top down sensu Fretwell 1977, Power 1992) food chain length to the distribution of green biomass (or eutrophic vs clearwater states in freshwaters). This coarse prediction provides a heuristic way of illustrating how ecosystem functioning is related to human health and economic well-being. For example, the importance of riparian and aquatic food chains can be communicated to nonscientists by considering water wells on the outskirts of Phoenix, Arizona, USA. These wells have been shut down because of toxic accumulations of nitrates. Residents of the region are literally drinking their own automobile exhaust (S. A. Fisher and N. B. Grimm, cited in Koppes 1990), because the arid, eroded, overgrazed watersheds collecting smog-laden precipitation from Phoenix support insufficient riparian or aquatic vegetation to assimilate this nitrogen into plant biomass. In functional food chain terms, these watersheds have no significant "trophic levels". If these watersheds supported one trophic level (sufficient plant growth to sequester nutrients), the wells would be less contaminated, but eutrophication could become a problem. Primary consumers could regulate plants, but if uncontrolled themselves, could give rise to pestiferous insect emergences. Predatory invertebrates and small fish (three trophic levels) would improve the situation, and if these and the grazers fed larger fish, birds, and wildlife, the ecosystem would provide recreation and aesthetic value, as well as animal protein. When contemporary citizens are asked by managers to evaluate "health" of aquatic systems, we usually give higher marks to systems with longer food chains (unless these are lengthened by exotic predators), and to aquatic systems with inverted pyramids of trophic level biomass. Food webs with inverted pyramids of trophic level biomass (Elton 1927) perform both bottom-up and top-down ecosystem services (sensu Daily 1997). They sustain the production of desirable carnivorous vertebrates (salmon, eels, eagles). These in turn may suppress organisms at lower trophic levels, which if left unchecked can produce nuisance or even health-jeopardizing conditions (eutrophication, insect pest outbreaks).

In undisturbed watersheds with intact natural vegetation, wetlands, and well-developed soils, food webs that channel nutrients into higher trophic levels are maintained by a number of factors and negative feedbacks (reviewed for lakes by Carpenter and Cottingham (1997); similar arguments apply in rivers, see Power et al. 1997). Shading and nutrient retention by terrestrial vegetation limit algal growth. Wetlands also sponge up nutrients, and add humics to water, which further inhibit algae by shading and metabolic effects (Jones 1992, Wetzel 1992). Under low algal productivity, bac- terial respiration is carbon limited so deeper waters stay oxygenated and phosphorus cycling from sediments is reduced. Wood imported from terrestrial forests, rootstabilized undercut banks, and aquatic macrophytes provide physical structures that retard bank erosion and shelter invertebrates and fish. Such habitats provide crucial refuges for prey and young life stages from predation, and from high flows during winter floods in rivers. Scour holes formed downstream from large logs in rivers also can provide aquatic life with wet "life boats" that sustain them through drought. Such habitats will support predator populations, which if sufficiently abundant, can lock up nutrients in their own long-lived biomass, further damping the accrual of algae. In the case of rivers, many of these long-lived consumers are also, literally, upwardly mobile. Salmon, bear, eagles, and bats can consume significant quantities of marine (Wipfli et al. 2000) and river-produced energy and nutrients (Rainey et al. 1992, Bilby et al. 1996, Ben-David et al. 1998, Power and Rainey 2000) and swim, walk, or fly it upstream or upslope. Thus, higher trophic levels keep nutrients high in the food web, and higher in the landscape, countering to some extent trends following human degradation of watersheds.

Unfortunately, the processes and feedbacks maintaining inverted pyramids of trophic level biomass in aquatic food webs are easily destroyed by land use. Timber removal, excessive sediment from roads, agricultural runoff, and channelization, diversion, and impoundment of rivers eliminate habitat structures required by key aquatic consumers or predators. Water bodies that receive more nutrients than their food webs can assimilate (e.g., from soil erosion, sewage, or agrochemicals) develop "bottom heavy" food webs characterized by blooms of undesirable (less edible) algae, and invertebrates tolerant of eutrophic conditions (e.g., hypoxia). Such webs support few or no top predators. The eutrophic state is, unfortunately, very stable, and may in some cases be irreversible (Carpenter et al. 1999). Can food chain theory help us to predict when we are close to the threshold of this state change, to manage against this change, or to determine which aquatic habitats have the potential to recover?

Food chain theory alone is not sufficient, but is useful as an element in expanded models that take into account all major sources and sinks for nutrients to water bodies. An expanded model of landscape controls on lake water quality (Carpenter et al. (1999) Fig. 3) includes the lake food web as just one of several potential sinks for nutrients that can eutrophy lakes (generally phosphorus in midwestern North America). This model summarizes conditions in which eutrophication of lakes might be reversed (e.g., by either increasing loss rates to sinks (biomanipulation of higher trophic levels, increasing lake outflow, immobilization of nutrients below the photic zone), or decreasing in- 
puts from sources (reducing inputs from watersheds, or by oxygenating the hypolimnion to reduce internal recycling from lake sediments). The model also depicts conditions under which lake eutrophication would probably not be reversible, by biomanipulation or any other management strategy. Eutrophication becomes irreversible when nutrient sources from the watershed or from internal recycling overwhelm all available or potential nutrient sinks (higher trophic levels, sedimentation out of the euphotic zone, outflowing rivers). This model counters a previous argument that aquatic systems that show trophic cascades tend to be more simple, homogeneous, and closed than terrestrial systems (Strong 1992, Polis and Strong 1996). In Carpenter et al.'s model, spatial heterogeneity (having a sediment compartment in which nutrients become unavailable to algae) or system openness (river washout of excess nutrients) enable, rather than preclude, trophic cascades that allow higher trophic levels to suppress plants.

\section{Delimiting spatio-temporal boundaries}

In Carpenter et al.'s model, the spatial domain was clearly delimited by the watershed divide around the lake. In most food web models, however, it is much less obvious how to delimit study systems in space

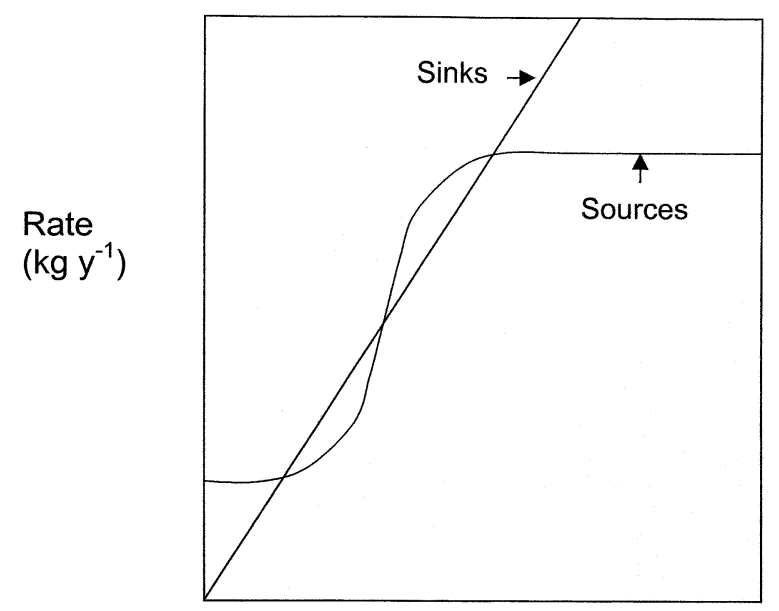

\section{$P$ Mass in Lake $(\mathrm{kg})$}

Fig. 3. Carpenter et al.'s (1999) model predicting resiliency of lakes subject to eutrophication from excessive nutrient (here phosphorus) loading. The rates of nutrient loss to sinks, and the rates of nutrient gains from watershed loading and internal recycling, determine whether various management measures (watershed mitigations, biomanipulation, sediment aeration to decrease nutrient solubility, or lake flushing) can succeed in restoring clear water conditions. Redrawn with permission from the author. and time for what physicists have called dynamical sufficiency (Thompson et al. in press). Consumers and their food resources can both move, but typically do so over different spatial scales. The "spatial domains pertinent to their population dynamics" (Holt 1996: 314) remain hidden from us, due to our ignorance of these movements. Yet they are central to management concerns focused on real landscapes. The spatial domains of consumers and resources determine species' habitat requirements (Schell et al. 1988), and their roles in contaminant transport (e.g., Cabana and Rasmussen 1994, Jackson 1997), both common management concerns. If we care about preserving species that occupy lands from which we want to extract other commodities (wood, water, building lots), we need to know what critical habitats and source areas and flow paths of the resources that sustain them, before these are inadvertently destroyed. These can include non-trophic resources, as for the endangered Coachella Valley fringe toed lizard, which requires a source of aeolian sand to maintain the shifting, unstable dune habitats in which they can outcompete other lizards (The Nature Conservancy unpubl.). Knowledge of the spatio-temporal origins of resources (i.e., an organism's "resource shed" (Power and Rainey 2000)) would assist us in managing populations, communities and ecosystems.

Ignorance of spatial scales of food webs is also one of the main reasons that we have so little ability to predict how trophic interactions will vary in different contexts, across space and time. This variation is of immediate relevance to many management problems. Predators, for example, will have stronger and more sustained local impacts where and when they are "subsidized" by resource from outside a local habitat (Polis et al. 1997). This can create conservation threats, for example for interior forest birds (e.g., wood thrushes or spotted owls) from agriculturally subsidized parasites, predators or competitors (brown headed cuckoos or barred owls, respectively).

Ecologists have some new conceptual and empirical tools that should accelerate the ongoing synthesis of landscape ecology with food web studies. Conceptual frameworks such as those provided by Holt (1996), Polis et al. (1997) and Cousins (1990) have stimulated much thinking about how food web interactions are spatially distributed. Concurrently, our ability to explore these ideas with field data is improving, due to clever applications of trophic tracers (e.g., stable or radioactive isotopes, persistent unique molecules, trace elements). An "unfolded food chain" network model by Higashi et al. (1989), although not written with explicit reference to food web tracers, will nonetheless be most useful in investigating the sources and fates of elemental constituents of organisms. In addition, 
new mapping technologies (such as airborne laser altimetry) allow ecologists to quantify and study increasingly large landscape features that contain and constrain trophic interactions.

I will briefly review applications of such tracers for obtaining spatially explicit food web information. I then will discuss their potential application to management of upland salmon-bearing rivers in coastal California, and in a floodplain river of Papua New Guinea, where mining threatens commercially harvested barramundi and over 100 other species of native fish.

\section{Use of tracers to delimit resource origins and movement histories of organisms}

Stable and radioactive isotopes, along with distinctive, persistent molecules like organochlorines or stable lipid residues, are proving increasingly useful in revealing spatial and temporal dimensions of food webs (Rundel et al. 1988, Schell et al. 1988, Schell and Ziemann 1988). There are many sources of variation for stable isotope composition of biological tissues (multiple potential sources and various physical and physiological fractionation processes), and consequently many opportunities for misinterpreting them. Nevertheless, technical innovations, diligence and clever detective work by ecologists are gradually turning more of this noise into signal, as sources of spatial and temporal variation in isotopes are identified (e.g., Schell and Ziemann 1988, Ben-David et al. 1998, Finlay et al. 1999).

Natural spatial variation in isotopes, (or tracer quantities experimentally introduced at known locations) can help ecologists reconstruct the space use histories of consumers assimilating some of these isotopes into their tissues (e.g., Ingram and Weber 1999). Consumers store resources for various lengths of time in tissues with different turnover rates. For example, vertebrate ear bones (e.g., fish otoliths) may retain for a lifetime atoms acquired during an animal's first days (Kalish 1990), while atoms in higher turnover tissues (e.g., fin webbing epithelium) may be completely exchanged within a few weeks. Therefore, a consumers conserved tissue records its lifetime resource shed (and part of its mother's, if individuals are sampled while their maternal endowments are still substantial, as is the case for newly emerged salmonids (Ingram and Weber 1999, Finlay et al. unpubl.). More labile tissues reflect areas used by consumers in their more recent past. As in watersheds (Dietrich et al. 1982), the area of an organism's "resource shed" expands with the time interval over which the consumer (or its mother) has acquired the constituents in question. How could reconstruction of this spatial history inform river management?

\section{Keystone habitats in upland salmon-rearing rivers}

Timber harvest conflicts with protection of salmonrearing habitats throughout western North America. The major environmental problem along the California North Coast is excessive loading of fine sediments into stream channels, due to roads and tree removal (Reid et al. 1981). At what rate can we cut timber, and still preserve sufficient channel habitat to sustain salmonids, and other populations (e.g., certain amphibians) of concern? Are certain landscape positions more ecologically important, or more fragile (prone to landslides or other forms of erosion; less biologically resilient) than others? (Hall and Lantz 1969, Northcote 1969, Waters 1995, Newcombe and Jensen 1996, Olson and Orr 1999).

To inform managers trying to balance timber extraction and fisheries preservation, it would be useful to identify critical "keystone" habitats. These would be analogues of Paine's keystone species (as redefined by Power et al. 1996b). Damage to these sites would greatly harm fish populations, with an effect disproportionate to the fraction of the basin area such habitats occupy.

Along the California Coast Range, canyon-bound rivers like the Eel have cut deeply into their beds, due to the rapid uplift of their mouths along the Mendocino Coast (Seidl and Dietrich 1992). As a result, there is little off-channel, lateral habitat to provide juvenile salmonids with refuge from deep water piscivores (e.g., larger salmonids, and now introduced pike minnows (Ptychocheilus grandis)) or high winter flows. This scarce habitat became even more severely limiting to salmonid production following the loss of important floodplain wetlands downstream, and the eradication of beaver and their dams (Naiman et al. 1988). Endangered coho salmon (Oncorhynchus kisutch) in particular need such habitat, because of their longer freshwater rearing period.

Given these geological and land use legacies, certain swampy meadows and forests that occur in unusually flat areas along upland and middle reach coastal California rivers may currently be keystone habitats. Swampy meadows along rivers on alluvial flats (Veirs 1996) are quite rare today. They store deep deposits of fine, organic rich sediment, held in place by redwoods (mostly mined out by now), alders, coarse sedges and other robust vegetation. Rivers divide into multiple deep channels as they thread through this vegetation. This creates excellent salmon-rearing habitat, with winter high flow refuge and summer cool water retreats. One small alluvial flat, a swampy sedge and alder meadow in the South Fork Eel drainage (used by locals as a town dump), contains most of the juvenile coho we have seen rearing in the South Fork basin. A rough estimate is that $>90 \%$ of the coho we have censused 
from 1995 to 1997 occurred in this habitat, which by area is $<1 \%$ of the channel habitat that we monitor in the South Fork Eel catchment (Power et al. unpubl.). The narrow braided channels cutting through deep peaty organic deposits in this meadow remain cool $\left(13^{\circ} \mathrm{C}\right)$ throughout the summer, when the mainstem downstream reaches temperatures of $24-26^{\circ} \mathrm{C}$. Alluvial flats can be eroded and destroyed following removal of standing and fallen trees from adjacent or downstream sites. If timber harvest or salvage (of dead wood in channels) cause deposits in alluvial flats to be excavated and lost, we would predict further declines in the watershed production of coho and other salmonids.

Before this experiment is carried out, it would be useful to know how much salmon (e.g., coho) production derives from an alluvial flat or some other putative keystone habitat. Such habitats might generate unique isotope signatures. For example, bacterial respiration of old peat might yield $\mathrm{CO}_{2}$ with a heavy $\left({ }^{13} \mathrm{C}\right.$ enriched) $\delta^{13} \mathrm{C}$ to local algae, microbes, or detritivorous invertebrates. Cooler water temperatures and prolonged groundwater storage might alter $\delta^{18} \mathrm{O}$. If natural abundances of isotopes did not distinguish energy sources from alluvial flats, tracers (e.g., $\left.\delta^{15} \mathrm{~N}\right)$ could be added to these habitats (e.g., Hershey et al. 1993). The contribution from these habitats to salmonid production could then be reconstructed, using non-lethal tissue samples (Kalish 1990, Ingram and Weber 1999, Finlay, et al., in review). Demonstrating that significant production of focal species derived from particular keystone habitats would motivate their preservation and restoration, even in watersheds subject to resource extraction at other sites.

\section{Isotopes as reconnaissance tools in the Fly River food web}

In the Ok Tedi and Fly Rivers of Papua New Guinea, Western Province (Fig. 4), fish biomass has declined dramatically downstream from the Ok Tedi Mine since gold, followed by copper, extraction commenced in 1985. Among a range of adverse environmental impacts of the mine, there is serious concern that acid rock drainage from deeper layers uncovered since 1999 may render copper in the tailings and rock waste deposited throughout the floodplain more bioavailable. (Apte et al. 1999, Environmental Geochemistry International 1999). Copper is particularly toxic to algae (Leland and Carter 1984, Stauber and Critelli 1993), so it is important to assess how much of the food web production in the Fly and Ok Tedi Rivers is algal-based. As in so many other environmental crises around the world, the area affected is enormous (the Middle Fly has a floodplain of ca $3000 \mathrm{~km}^{2}$ (Dietrich et al. 1999)). Isotope surveys can provide a quick, synoptic overview of feed-

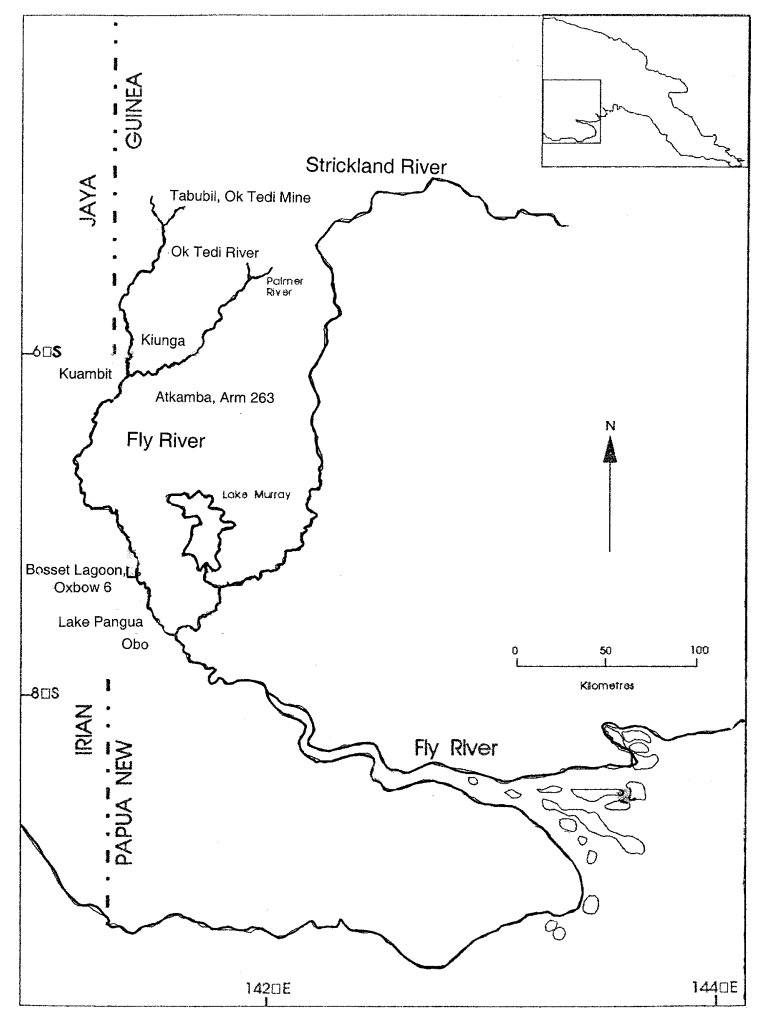

Fig. 4. Map of the Ok Tedi and Fly Rivers, both affected by the Ok Tedi Mine in Tabubil. Transitions between the upper forested floodplain and the lower grassed floodplain on the middle Fly occur above Manda. Fishes were collected from Kuambit, with additional samples of Nematolosa (herring) from the Obo floodplain and Oxbow 6. Algae were collected from Kuambit and Lake Pangua.

ing relationships and energy sources that are useful for rapid reconnaissance in these situations.

In a pilot sampling effort in 1994-1995, I collected algae, macrophytes, zooplankton, floodplain insects, fishes, and scales from a small crocodile from the $\mathrm{Ok}$ Tedi and Fly River downstream from the mine (Fig. 4) for stable isotope food web analysis (Power et al. 1995). More samples were subsequently collected in 1998 by Bunn et al. (1999). I collected most of my samples from a research vessel or a motorized dinghy in April 1994, at a time when river stage was high, near the maximum for the year. This period had followed a drought, which had allowed extensive filling of off-river water bodies with grasses. Macrophytes and algal mats were collected from Lake Pangua in the lower grassed floodplain (Fig. 4). Zooplankton were collected here by towing a $110-\mu \mathrm{m}$ mesh plankton net slowly behind a motorized dinghy inside a peripheral weed bed (littoral sample) and across the open water of the center of the lake (limnetic sample). A similar zooplankton plankton tow was made nearby in the main channel of the Fly River. (Visual microscopic examination showed the main channel sample to be free of zooplankton.) A 
phytoplankton tow ( $80-\mu \mathrm{m}$ mesh net) was made at the terminal end of Lake Pangua on 15 July 1994. This materially was scanned at $400 \times$, and revealed Spirogyra, Ankistrodesmus, Volvox, and single-celled desmids (few cyanobacteria and no diatoms were seen in phytoplankton.) However, phytoplankton quantity was insufficient for an isotope analysis. Insects attracted to the lights of the research vessel during the night were collected when the ship docked at Obo, near Lake Pangua in the grassy Fly floodplain (Fig. 4) on the night of 2 April. Macrophytes, algae, and insects were also collected in the forested floodplain up river from Arm 263 (near Atkamba) on 3 April.

Fishes (except for the freshwater herring Nematolosa spp) were collected by gill netting led by an Ok Tedi fish crew on 4 April 1994, near Kuambit (Figs 4, 5). Samples were strips of muscle, with scales, cut from the lower ventral body wall of each fish. Individual fish samples were stored, dried, and analyzed separately. Algae were also collected near this site. Nematolosa samples were collected by A. Storey on the Obo floodplain on 4 December 1994, and from Oxbow 6 near Bossett (Fig. 4) on 24 June 1994. This species is the primary prey of the top predator fish, Lates calcarifer. Sloughing scales peeled from a $67-\mathrm{cm}-1$ ong juvenile crocodile brought to the Environmental Division at Tabubil (Fig. 4) were also analyzed.

The $\delta^{15} \mathrm{~N}$ of these samples reflects the expected enrichment of the heavier stable isotope as one goes up the food chain (Fig. 5), although these data show somewhat less than the $0.3 \%$ enrichment observed per trophic transfer in many other ecosystems (Minagawa and Wada 1984, Cabana and Rasmussen 1994, Kling et al. 1992). Carbon isotope ratios $\left(\delta^{13} \mathrm{C}\right)$ of many organisms fell within a narrow range of -25 to $-28 \mathrm{ppt}$ (Fig. 5). Primary producers with these carbon ratios included periphyton scraped from macrophyte surfaces as well as some C3 macrophytes (bladderwort Utricularia, Polygonum, and the aquatic fern Azolla). In the grassy floodplain, dense monospecific stands of wild sugarcane (Saccharum robustum) line the channel. These, and other $\mathrm{C} 4$ grasses common on the inland floodplain, including Leersia hexandra and leaves and seed heads of Hymenachne acutigluma, had enriched $\delta^{13} \mathrm{C}$ values characteristic of $\mathrm{C} 4$ plants (Fig. 5). Despite the dominance of $\mathrm{C} 4$ producer biomass bordering the channel on the grassed floodplain, few consumers appeared to derive their carbon from these plants. Only two terrestrial invertebrates sampled, katydids (Orthoptera) and a slender sap sucking bug Leptocorisa sp. (Alydidae (Coviscidae) Hemiptera) had signatures indicating significant $\mathrm{C} 4$ contribution. The aquatic invertebrates and herring collected in the grassed floodplain had ${ }^{13} \mathrm{C}$ signatures consistent with those of the local periphyton. Seven species of ariid and plotosid catfishes, a sciaenid, Nibea semifasciata, archer fish (Toxotes chatareus), and barramundi gill netted near Kuambit
(Fig. 4) also had isotope signatures consistent with $\mathrm{C} 3$ vegetation and the $\delta^{13} \mathrm{C}$ of green algal mats and golden brown epiphytes collected near that site. Barramundi are the only fish that are harvested commercially from the Fly River at present. One large $(7.5 \mathrm{~kg})$ specimen had a signal consistent with one derived (through their major prey, the herring Nematolosa spp.) from algal carbon. A second $2.0-\mathrm{kg}$ barramundi from the same site had $a{ }^{13} \mathrm{C}$ that was slightly enriched over that of the larger Lates $(-27$ versus -32.5 ) but still consistent with contributions derived from the algae we sampled near Kuambit (algal $\delta^{13} \mathrm{C}$ from -28.5 to -32 ). We cannot rule out the contribution of some of the $\mathrm{C} 3$ macrophytes or terrestrial trees as energy sources, based on our data. However, diatoms, common in the periphyton coating submerged grasses and macrophytes, and on which the herring were frequently seen browsing, are

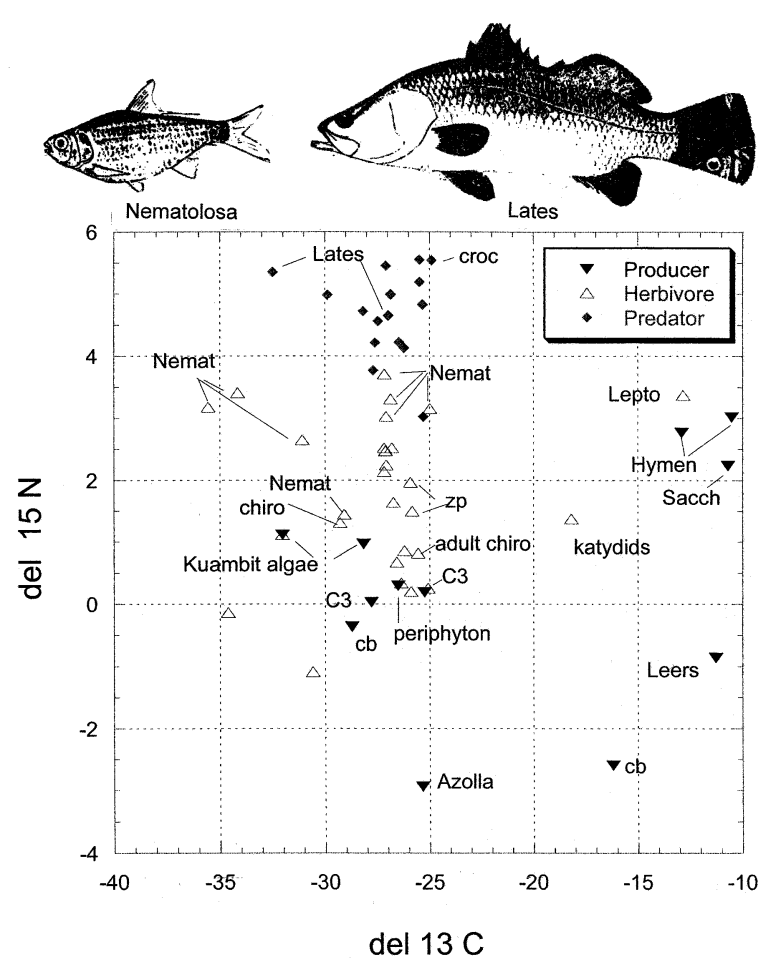

Fig. 5. Dual isotope plot of organisms sampled from the Fly River food web from 1994-1995. C4 grasses: Sacch = Saccharum robustum; Hymen = Hymenachne sp. leaves and seed heads. Other primary producers: $\mathrm{cb}=$ cyanobacteria, and $\mathrm{C} 3=$ two macrophytes, Utricularia (more enriched 13C, and Polygonum. Primary consumers: Lepto $=$ Leptocorisa $\mathrm{sp} . ; \mathrm{zp}=$ littoral and open water zooplankton from L. Pangua; chiro $=$ chironomid larvae; adult chiro = adult chironomids; Nemat = Nematolosa flyensis and N. papuensis ("Nemat" nine individuals shown, two points superimposed). Other unlabelled primary consumers are various terrestrial insect orders collected from the floodplain. Predators: Lates $=$ Lates calcar ifer; $\operatorname{croc}=$ juvenile crocodile, predatory and omnivorous catfishes and croakers (Plotosidae, Ariidae, and Sciaenidae) shown as unlabelled predator points. More details are given in Power et al. 1995. 
known to be superior as food to vascular plants and their detritus (Boyd 1973, Power 1983, Kupferberg et al. 1994). In a more thorough isotope study, Forsberg (1993) concluded that Amazonian floodplain fishes were built of algal-derived carbon rather than the locally dominant C4 grasses (Echinochloa and Paspalum). Bunn et al. (1999), sampling from two other sites (Kawok, in the upper Forested Fly and Oxbow 6, in the Middle Fly at the forest-grass transition), came to similar conclusions about the importance of algae as an energy source to the food web, although their data also could not rule out possible contributions of $\mathrm{C} 3$ plants to consumers.

A plausible conclusion from these preliminary sampling efforts is that fish and invertebrates in the Fly River could ultimately derive much of their carbon from algae. The Fly River habitat has been severely damaged by tailings sediments, but the ecosystem could recover as the river re-excavates its natural channel during the decades following mine life (Cui and Parker 1999). Ecosystem devastation from copper toxicity, on the other hand, will be long term (virtually permanent on a human time scale), particularly if the aquatic food web is largely algal-based.

In this and other applications of isotopes as food web tracers, ambiguities remain, particularly when only a few tracers are available. Applications of these tools, however, are rapidly converting large-scale ecological studies into research efforts with clearly defined, falsifiable hypotheses. The range of competing hypotheses can be narrowed as more different tracers (stable and radioisotopes, trace elements, fatty acid residues, and other unusual atoms and molecules that have spatiotemporally distinct distributions in nature) are brought to bear on the same problem. This progress will make field biology considerably more useful in providing information at scales needed to resolve management issues.

\section{Conclusions}

Food chain models may be useful for initially framing resource management problems. The most useful models will be dynamic (attempting to predict the future from present states and process rates), comprehensive (with sufficient scope to encompass key gain and loss processes operating over many $\mathrm{km}^{2}$, and years to decades, the scales commonly needed for natural resource management), and initially simple. To make useful specific predictions, however, we generally need to resolve dynamically important details peculiar to particular situations and problems. Given the complexity of ecological systems, we must anticipate surprises that our models will not predict. We should continue the attempt, however, because attempts at prediction makes us faster at postdiction. Rapid iterations between field observations and improving models prepare ecologists for quickly interpreting why ecosystem trajectories may have taken certain turns. Revised assessments have more chance then of helping decision makers recognize looming disasters (irreversible state changes) in time to change plans of action. Food web models will also become more useful to management as they are cast in more explicit landscape contexts. We are making surprising progress here, with the use of remote sensing technology and food web tracers that yield clues about the movements of organisms and the spatial sources of their constituent elements. While the challenges that remain are great, so are both the need and the hope for increasing the usefulness of food web models and field studies for management.

Acknowledgements - Many thanks to Joel Brown and Os Schmitz for their thoughtful reviews of this paper, and to Tarja and Lauri Oksanen for their thought-provoking discussions. I thank Tarja Oksanen for organizing this stimulating Nordic Ecology course. Jacques Finlay, Gilbert Cabana and Bill Rainey have educated me about food web tracers. For the Papua New Guinea field work, I thank the Ok Tedi Mining Co. for logistical support, Monica Rau for identification of macrophytes and inspiration, Tom Weir of the CSIRO Entomology Museum in Canberra for insect identifications, Andy Maie for allowing me to sample fish collected by his gill netting crew, Andrew Storey for Nematolosa samples, and Geoff Day for logistical assistance and transportation in the field. Bill Dietrich provides continual help and inspiration. The Water Resources Center of California and the National Science Foundation provided financial support.

\section{References}

Apte, S. C., Simpson, S. L. and Webster, I. T. 1999. Geochemical modelling and prediction of copper speciation in the Fly River system. - Available at 〈http:/ www.OkTedi.com/environment/papers.htm $>$.

Arrow, K., Bolin, B., Costanza, R. et al. 1995. Economic growth, carrying capacity, and the environment. - Science 268: $520-521$

Ben-David, M., Hanley, T. A. and Schell, D. M. 1998. Fertilization of terrestrial vegetation by spawning Pacific salmon: the role of flooding and predator activity. - Oikos 83: 47-55.

Bilby, R. E., Fransen, B. R. and Bisson, P. A. 1996. Incorporation of nitrogen and carbon from spawning coho salmon into the trophic system of small streams: evidence from stable isotopes. - Can. J. Fish. Aquat. Sci. 53: 164-173.

Boyd, C. E. 1973. Amino acid composition of freshwater algae. - Arch. Hydrobiologia 72: 1-9.

Bunn, S., Tenakanai, C. and Storey, A. 1999. Energy sources supporting Fly River fish communities. - Report to the $\mathrm{Ok}$ Tedi Miniming Limited Environmental Department, May 1999

Cabana, G. and Rasmussen, J. B. 1994. Modelling food chain structure and contaminant bioaccumulation using stable nitrogen isotopes. - Nature 372: 255-257.

Carpenter, S. R. and Kitchell, J. F. 1984. Plankton community structure and limnetic primary production. - Am. Nat. 124: $159-172$.

Carpenter, S. R. and Kitchell, J. F. 1992. The trophic cascade in lake ecosystems. - Cambridge Univ. Press.

Carpenter, S. R. and Cottingham, K. L. 1997. Resilience and restoration of lakes. - Conserv. Ecol. [online] 1(1): 2. Available at: 〈http://www.consecol.org/vol1/iss1/art2 $\rangle$. 
Carpenter, S. R., Kitchell, J. F. and Hodgson, J. R. 1985 Cascading trophic interactions and lake productivity. BioScience 35: 634-649.

Carpenter, S. R., Kitchell, J. F., Hodgson, J. R. et al. 1987. Regulation of lake primary productivity in food web structure. - Ecology 68: 1863-1876.

Carpenter, S. R., Ludwig, D. and Brock, W. A. 1999. Management of eutrophication for lakes subject to potentially irreversible change. - Ecol. Appl. 9: 751-771.

Chadwick, O. A., Derry, L. A., Vitousek, P. M. et al. 1999. Changing sources of nutrients during four million years of ecosystem development. - Nature 397: 491-497.

Chamberlin, T. C. 1890. The method of multiple working hypotheses. - Science 15: 92-96.

Cousins, S. H. 1990. Countable ecosystems deriving from a new food web entity. - Oikos 57: 270-275.

Cui, Y. and Parker, G. 1999. Sediment transport and deposition in the Ok Tedi-Fly River system, Papua New Guinea: the modelling of 1998-1999. - Report to Ok Tedi Mining Ltd. Available at 〈http://www.OkTedi.com/environment/ papers.htm $\rangle$.

Daily, G. C. (ed.) 1997. Nature's Services. - Island Press.

DeMelo, R., France, R. and McQueen, D. J. 1992. Biomanipulation: hit or myth? - Limnol. Oceanogr. 37: 192-207.

Dietrich, W. E., Dunne, T., Humphrey, N. F. and Reid, L. M. 1982. Construction of sediment budgets for drainage basins - U.S. For. Serv. Gen. Tech. Rep. PNW-141: 5-23.

Dietrich, W. E., Day, G. and Parker, G. 1999 The Fly River, Papua New Guinea: inferences about river dynamics, floodplain sedimentation and fate of sediment. - In Miller, A. J. and Gupta, A. (eds), Varieties of fluvial form. Wiley, pp. 345-376.

Elton, C. S. 1927. Animal ecology. - Sidgwick and Jackson.

Environmental Geochemistry International. 1999. Acid drainage and metal leaching potential of waste rock tailings. - Available at 〈http://www.OkTedi.com/ environment/papers.htm $>$.

Finlay, J. C., Power, M. E. and Cabana, G. 1999. Effects of carbon limitation on algal carbon isotope ratios: implications for river food webs. - Limnol. Oceanogr. 44: 11981203.

Finlay, J. C., Khandwala, S. and Power, M. E. 2001. The spatial scales of energy flow in food webs of the South Fork Eel River. (in review)

Forsberg, B. R. 1993. Autotrophic carbon sources for Amazon fish? - Ecology 74: 643-652.

Fretwell, S. D. 1977. The regulation of plant communities by food chains exploiting them. - Persp. Biol. Med. 20: $169-185$.

Frost, T. M., DeAngelis, D. L., Bartell, S. M. et al. 1988. Scale in the design and interpretation of aquatic community research. - In: Carpenter, S. R. (ed.), Complex interactions in lake communities. Springer-Verlag, pp. 229-258.

Getz, W. M. 1984. Population dynamics: a per capita resource approach. - J. Theor. Biol. 108: 623-643.

Hall, J. D. and Lantz, R. L. 1969. Effects of logging on the habitat of coho salmon and cutthroat trout in coastal streams. - In: Northcote, T. G. (ed.), Symposium on salmon and trout in streams. Univ. of British Columbia, Vancouver, BC, pp. 355-375.

Hershey, A. E., Pastor, J., Peterson, B. J. and Kling, G. W 1993. Stable isotopes resolve the drift paradox for Baetis mayflies in an Arctic River. - Ecology 74: 2315-2325.

Higashi, M., Burns, T. P. and Patten, B. C. 1989. Food network unfolding: an extension of trophic dynamics for application to natural ecosystems. - J. Theor. Biol. 140 243-261.

Holling, C. S. (ed.) 1978. Adaptive environmental assessment and management. - Wiley.

Holt, R. D. 1996. Food webs in space: an island biogeographic perspective. - In: Polis, G. W. and Winemiller, K. O. (eds), Food webs. Chapman and Hall, pp. 313-323.
Ingram, B. L. and Weber, P. K. 1999. Salmon origin in California's Sacramento-San Joaquin river system as determined by otolith strontium isotopic composition. - Geology 27: $851-854$.

Jackson, L. J. 1997. Piscivores, predation, and PCBs in Lake Ontario's pelagic food web. - Ecol. Applic. 7: 991-1001.

Jones, R. I. 1992. The influence of humic substances on lacustrine planktonic food chains. - Hydrobiologia 229: 73-91.

Kalish, J. M. 1990. Use of otolith microchemistry to distinguish the progeny of sympatric anadromous and nonanadromous salmonids. - Fish. Bull. 88: 657-666.

Kitchell, J. F. (ed.) 1992. Food web management. - Springer Verlag.

Kling, G. W., Fry, B. and O'Brien, W. J. 1992. Stable isotopes and planktonic trophic structure in arctic lakes. - Ecology 73: $561-566$

Koppes, S. 1990. Delving into desert streams. - Ariz. State Univ. Res. 5: 16-19.

Kupferberg, S. J., Marks, J. C. and Power, M. E. 1994. Effects of variation in natural algal and detrital diets on larval anuran (Hyla regilla) life history traits. - Copeia 1994: 446-457.

Leibold, M. A. 1989. Resource edibility and the effects of predators and productivity on the outcome of trophic interactions. - Am. Nat. 134: 922-949.

Leland, H. V. and Carter, J. L. 1984. Effects of copper on species composition of periphyton in a Sierra Nevada, California, stream. - Freshw. Biol. 14: 281-296.

Levin, S. A. 1996. Forum: economic growth and environmental quality. - Ecol. Appl. 6: 12-32.

Levin, S. A. and Pacala, S. W. 1997. Theories of simplification and scaling of spatially distributed processes. - In: Tilman, D. and Kareiva, P. (eds), Spatial ecology: the role of space in population dynamics and interspecific interactions. Princeton Univ. Press, pp. 271-295

Martin, G. 1998. California's Galapagos. -San Francisco Chronicle, January 19, 1998: pp. 1-4.

McQueen, D. J., Post, J. R. and Mills, E. L. 1986. Trophic relationships in freshwater pelagic ecosystems. - Can. J. Fish. Aquat. Sci. 43: 1571-1581.

Menge, B. A. and Farrell, T. M. 1989. Community structure and interaction webs in shallow marine hard-bottom communities: tests of an environmental stress model. - Adv. Ecol. Res. 19: 146-156.

Minagawa, M. and Wada, E. 1984. Stepwise enrichment of ${ }^{15} \mathrm{~N}$ along food chains: further evidence and the relation between $\delta^{15} \mathrm{~N}$ and animal age. - Geochim. Cosmochim. Acta 48: $1135-1140$.

Naiman, R. J., Johnston, C. A. and Kelley, J. C. 1988. Alteration of North American streams by beaver. - Bioscience 38: 753-762.

Newcombe, C. P. and Jensen, J. O. T. 1996. Channel suspended sediment and fisheries: a synthesis for quantitative assessment of risk and impact. - North Am. J. Fish. Manage. 16: 693-727.

Northcote, T. G. 1969. Symposium on salmon and trout in streams. Macmillan.

Oksanen, L. 1991. Trophic levels and trophic dynamics: a consensus emerging? - Trends Ecol. Evol. 6: 58-60.

Oksanen, L., Fretwell, S. D., Arruda, J. and Niemelä, P. 1981. Exploitation ecosystems in gradients of primary productivity. - Am. Nat. 118: 240-261.

Olson, C. M. and Orr, B. 1999. Combining tree growth, fish and wildlife habitat, mass wasting, sedimentation, and hydrologic models in decision anaysis and long-term forest land planning. - For. Ecol. Manage. 114: 339-348.

Polis, G. A. and Strong, D. R. 1996. Food web complexity and community dynamics. - Am. Nat. 147: 813-846.

Polis, G. A., Anderson, W. B. and Holt, R. D. 1997. Toward an integration of landscape and food web ecology: the dynamics of spatially subsidized food webs. - Annu. Rev. Ecol. Syst. 28: 289-316. 
Porter, K. G. 1973. Selective grazing and differential digestion of algae by zooplankton. - Nature 244: 179-180.

Power, M. E. 1983. Grazing responses of tropical freshwater fishes to different scales of variation in their food. Environ. Biol. Fish. 9: 103-115.

Power, M. E. 1992. Top down and bottom up forces in food webs: do plants have primary? - Ecology 73: 733-746.

Power, M. E. and Rainey, W. E. 2000. Food webs and resource sheds: towards spatially delimiting trophic interactions. - In: Hutchings, M. J., John, E. A. and Stewart, A J. A. (eds), Ecological consequences of habitat heterogeneity. Blackwell Scientific, pp. 291-314.

Power, M. E., Rau, M. and Tenakanai, C. D. 1995. Preliminary description of food web structure of the Fly River, Papua New Guinea, based on inferences from stable isotopes. - Report to Ok Tedi Mining Ltd., Environment Department.

Power, M. E., Dietrich, W. E. and Finlay, J. C. 1996a. Dams and downstream aquatic biodiversity: potential food web consequences of hydrologic and geomorphic change. Environ. Manage. 20: 887-895.

Power, M. E., Tilman, D., Estes, J. et al. 1996b. Challenges in the quest for keystones. - BioScience 46: 609-628

Power, M. E., Kupferberg, S. J., Minshall, G. W. et al. 1997. Sustaining western aquatic food webs. - In: Minckley, W. C. (ed.), Aquatic ecosystems. Report to the Western Water Policy Review, a Presidential Advisory Commission. Tempe, AZ, pp. 45-61.

Rainey, W. E., Pierson, E. D., Colberg, M. and Barclay, J. H 1992. Bats in hollow redwoods: seasonal use and role in nutrient transfer into old growth communities. - Bat Res. News 33: 71.

Reid, L. M., Dunne, T. and Cedarholme, C. J. 1981. Application of sediment budget studies to the evaluation of logging road impact. - J. Hydrol. 20: 49-62.

Rundel, P. W., Ehleringer, J. R. and Nagy, K. A. 1988. Stable isotopes in ecological research. - Springer.

Schell, D. M. and Ziemann, P. J. 1988. Natural carbon isotope tracers in Arctic aquatic food webs. - In: Rundel, P. W. Ehleringer, J. R. and Nagy, K. A. (eds), Stable isotopes in ecological research. Springer-Verlag, pp. 230-251.

Schell, D. M., Saupe, S. M. and Haubenstock, H. 1988 Natural isotope abundances in Bowhead whale (Balaena mysticetus) Baleen: markers of aging and habitat usage. In: Rundel, P. W., Ehleringer, J. R. and Nagy, K. A. (eds) Stable isotopes in ecological research. Springer-Verlag, pp. 260-269.

Schmitz, O. J., Hambäck, P. A. and Beckerman, A. P. 2000. Trophic cascades in terrestrial systems: a review of the effects of carnivore removals on plants. - Am. Nat. 155: $141-153$.
Seidl, M. A. and Dietrich, W. E. 1992. The problem of channel erosion into bedrock. - Catena Suppl. 23: 101124.

Shapiro, J. 1979. The importance of trophic-level interactions to the abundance and species composition of algae in lakes. - In: Barica, J. and Mur, L. (eds), Hypertrophic ecosystems. Junk, pp. 105-116.

Smith, F. 1969. Effects of enrichment in mathematical models. - In: Eutrophication: causes, consequences, correctives National Academy of Sciences, Washington, DC, pp. 631645

Starfield, A. M. and Bleloch, A. L. 1986. Building models for conservation and wildlife management. - Macmillan.

Stauber, J. L. and Critelli, C. 1993. Toxicity of waters from the Fly river system to freshwater and estuarine algae. CSIRO Investigation Report CET/IR187.

Strong, D. R. 1992. Are trophic cascades all wet? Differentiation and donor-control in speciose ecosystems. - Ecology 73: $747-754$

Sykes, R. M. 1973. The trophic-dynamic aspects of ecosystem models. - Proc. 16th Conf. Great Lakes Res. 1973: 977988.

Thompson, J. N., Reichman, O. J., Morin, P. J. et al. Frontiers of Ecology. - BioScience (in press)

Turchin, P. 2001. Does population ecology have general laws? Oikos 94: 17-26.

Veirs, S. D. 1996. Ecology of the Coast Redwood - In: Leblanc, J. (ed.), Conference on Coast Redwood forest ecology and mangement. Univ. of Calif. Coop. Extension, Forestry.

Vitousek, P. M., Mooney, H. A., Lubchenco, J. and Melillo, J M. 1997. Human domination of earth's ecosystems. Science 227: 494-499.

Walters, C. 1986. Adaptive management of renewable resources. - Macmillan.

Waters, T. F. 1995. Sediment in streams: sources, biological effects, and control. American Fisheries Society Monograph.

Weisberg, S. B. and Burton, W. H. 1993. Enhancement of fish feeding and growth after an increse in minimum flow below the Conowingo Dam. - N. Am. J. Fish Manage. 13: $103-109$.

Wetzel, R. G. 1992. Gradient-dominated ecosystems: sources and regulatory functions of dissolved organic matter in freshwater ecosystems. - Hydrobiologia 229: 181-198.

Wipfli, M. S., Hudson, J. P., Chaloner, D. T. et al. 2000. Marine, freshwater and riparian linkages: salmon carcasses fuel riverine food webs in Alaska. - Bull. NABS 17: 106.

Wootton, J. T. 1994. Predicting direct and indirect effects: an integrated approach using experiments and path analysis. - Ecology 75: 151-165.

Wootton, J. T., Parker, M. S. and Power, M. E. 1996. Effects of disturbance on river food webs. - Science 273: 1558 1560 . 